Arab World English Journal (AWEJ) Volume 12. Number1 March 2021

DOI: https://dx.doi.org/10.24093/awej/vol12no1.24

Pp.357-373

\title{
Utilizing Learners' Linguistic Landscape as a Pedagogical Resource in the Translation Classroom: A case study in the Sultanate of Oman
}

\author{
Ali Algryani \\ Department of English Language and Literature, \\ College of Arts and Applied Sciences, \\ Dhofar University, Salalah, Oman \\ \& Department of English Language and Translation, \\ School of Languages, The Libyan Academy, Tripoli, Libya \\ correspondent Author: aalgryani@du.edu.om \\ Syerina Syahrin \\ Department of English Language and Literature, \\ College of Arts and Applied Sciences, \\ Dhofar University, Salalah, Oman
}

Received: 12/30/2020

Accepted: 2/20/202

Published: 3/24/2021

\section{Abstract}

The study investigates learners' awareness of their linguistic landscape (LL) and perspectives on the use of LL as part of classroom teaching and learning. It also examines the course instructor's pedagogical perspective on the use of LL. The study aims to explore the potential benefits of utilizing bilingual public signage representing translational content to develop translation students' critical literacy, language awareness, and translation skills through reflecting on the use of LL as a teaching and learning material. The study is significant as it addresses the gap in the literature on the use of LL to promote students' critical literacy, language awareness, and translation skills in the EFL context of Oman. The samples of the study are 58 participants enrolled in undergraduate translation courses at Dhofar University. The data collection methods used in the study consist of focus group discussions, online surveys, and teacher's retrospective reflection. The quantitative data were analyzed by IBM SPSS V26, while the qualitative data were analyzed by common themes that emerged from students' feedback and teacher's reflection. The findings of the study showed positive outcomes on the use of LL as a teaching and learning resource such as improved language awareness, language proficiency, translation skills, creativity, and critical thinking skills. The implication of the study is to draw attention to the existing quality of the learners' LL and invite them to actively and responsibly participate in improving the linguistic landscapes of their local communities.

Keywords: EFL, linguistic landscape, public signage, Sultanate of Oman, translation

Cite as: Algryani, A., \& Syahrin, S. (2021). Utilizing Learners' Linguistic Landscape as a

Pedagogical Resource in the Translation Classroom: A case study in the Sultanate of

Oman. Arab World English Journal, 12 (1) 357-373.

DOI: https://dx.doi.org/10.24093/awej/vol12no1.24 
Arab World English Journal (AWEJ) Volume 12. Number 1. March 2021

Utilizing Learners' Linguistic Landscape as a Pedagogical Resource

Algryani \& Syahrin

\section{Introduction}

Landscape Linguistics as a field of study was introduced by Landery and Bourhis (1997). Generally speaking, the linguistic landscape (LL) of a territory or urban agglomeration is defined as language scripts on public road signs, commercial signs, advertising billboards, and signs on government buildings.

Linguistic landscape, as an object of research, has been studied from a variety of perspectives. For instance, recent studies such as those of Ben-Rafael, Shohamy, Amara \& Trumper-Hecht (2006), Gorter (2006, 2013), Backhaus (2007), Shohamy and Gorter (2009), Spolsky (2009), Kasanga (2012) among others, approached linguistic landscape from applied linguistics and sociolinguistics perspectives, paying special attention to language use, policy, identity, ideology and awareness in the public sphere. Furthermore, there have been several attempts to explore LL from an educational perspective (e.g. Shohamy \& Waksman 2009; Sayer 2010; Hewitt-Bradshaw 2014; Gorter \& Cenoz 2015; Malinowski, 2015; Roos \& Nicholas, 2019; Wiśniewska 2020). In such works, LL is seen as "a site of language and literacy learning" (Malinowski, 2015, p. 95) as it can be utilized as an educational tool to help learners develop language awareness, understanding, and communicative competencies (Hewitt-Bradshaw, 2014).

The use of LL as a teaching and learning resource has been described in several studies. Hewitt-Bradshaw (2014), for instance, points out that LL promotes "the social context of language learning and language use, and offers educators many opportunities to create meaningful experiences for learners" (pp. 159-160). Through the use of LL as an educational tool, learners are engaged in literacy activities outside classroom contexts, thus relating their classroom learning experiences to the linguistic practices in their communities of existence (Hewitt-Bradshaw, 2014). This can help learners develop knowledge of text genres, language use, and appropriateness in a given context, etc. Furthermore, LL can also be a useful tool for teaching learners about language awareness via, for instance, classroom activities aiming to explore language contact in students' communities to develop their knowledge of language diversity (Dagenias, Moore, Sabatier, Lamarre \& Ahmed, 2009). Finally, as pointed out by Sayer (2010), the use of LL as a resource for teaching develops learners' awareness of the role of languages used for communication in their communities.

There is a gap in the current literature on the use of LL to promote students' linguistic competence, language awareness, and translation skills in the EFL context of Oman. The current study is an attempt to examine whether the utilization of students' linguistic landscape can contribute to the enhancement of their language awareness, translation, and literacy skills.

The rationale for investigating the students' language awareness, translation skills, and critical literacy through the use of LL is to provide an additional pedagogical resource in the teaching and learning of language and translation courses. The study is significant as it supports the view that by exposing students to their LL, they are expected to be able to identify and examine closely the relevance and significance of the languages used in their communities. Through the use of LL, the participants of the study were offered the opportunity to maximize the use of real-life language in their local context (Floralde \& Valdez, 2017). The participants provided input on the existing translations of their LL, the languages used in their local communities, and its functions through active engagement in critical thinking activities and 
classroom discussions. The students aspire to be the agents of change in the future by ensuring that the LL of their environments is well-represented. Critical thinking skills, active communication, and participating in the community for the development of the Sultanate are important aspects of Oman Vision 2040.

The study aims to enhance language awareness, translation skills, and critical literacy among the participants of the study through the use of LL in classroom teaching and learning. Paramount to achieving these aims is an investigation that looks at these specific areas:

1. To determine the participants' awareness of their linguistic landscape,

2. To document the perspectives of the participants on the use of the LL as part of the classroom teaching and learning,

3. To explore the effectiveness of LL as a teaching and learning resource for translation courses.

The study is framed by the following research questions:

1. How do the participants report their awareness of the linguistic landscape of their community?

2. What are the perspectives of the participants on the use of the linguistic landscape as part of the classroom teaching and learning?

3. How does the course instructor report the outcome of the lesson delivery utilizing LL as a teaching and learning resource?

\section{Literature Review}

Numerous studies have investigated the use of the linguistic landscape as a teaching and learning resource. To begin with, in his survey of LL research, Gorter (2017) points out that "the linguistic landscape in an educational context provides a promising way to teach about languages, multilingualism, language awareness, and literacy practices". Wiśniewska (2020) studied the relationship between linguistic landscape, murals, and language learning and found out that "the linguistic landscape provides verbal and visual input for language learning" (p.429). Wiśniewska concluded that the use of linguistic landscape materials and murals provides learners with opportunities to develop their language skills and enhance discussing and thinking about such materials within their socio-cultural contexts, resulting in "combining language learning, content learning, and development of social, political, and art awareness" (p. 441).

Roos and Nicholas (2019) conducted a study on the use of learners' linguistic landscape (language environments) for EFL learning in German primary schools. The study aimed at finding out how primary school students engage with English texts in their communities. The results of the study showed that the use of LL provides EFL learners with authentic learning materials and "opportunities to learn about the 'foreign' language in ways that contribute to their general (language) learning, about their own culture and language as well as about themselves and their (cultural) diversity" (Roos \& Nicholas, 2019, p. 108). Moreover, the study reported that students' reflections about the languages used in their local linguistic landscapes helped them develop an awareness of linguistic diversity in their local communities.

In the same vein, Hewitt-Bradshaw (2014) studied the benefits of utilizing linguistic landscape texts as an educational tool for developing learners' literacy in Caribbean Creole environments. The study shows that the use of public texts in classroom settings not only 
develops students' language awareness and communicative competence but also renders the process of language learning more interesting and appealing. Furthermore, the use of learners' LL in teaching activities make students aware of the linguistic characteristics of the LL in their environments and help learners recognize that LL is a space where different players, such as advertisers, politicians, etc, exercise their influence in the society, which results in developing "students' critical literacy as well as their pragmatic competence" (Hewitt-Bradshaw, 2014, p.172).

A study carried out by Cenoz and Gorter (2008) explored the role of linguistic landscapes as a source of input for second and foreign language acquisition with a special reference to the acquisition of pragmatic competence. The study concluded that language scripts of public signage can serve as authentic input for language learners and can enhance learners' language awareness. Furthermore, in their study, Cenoz and Gorter (2008) identified five areas of learning as potential pedagogical benefits of exploring and using LL. These are incidental learning, pragmatic competence, multimodal literacy skills, multicompetence, and the symbolic and emotional power of language. It has been reported in other studies that the use of English in the public sphere can express social meanings such as prestige, modernity, and associations with English-speaking cultures (Blommaert, 1996; Backhaus 2007, Torkington, 2009).

Sayer (2010) investigated the use of the linguistic landscape as a pedagogical resource in the EFL classroom in Oaxaca, Mexico. He used public signs to analyze the different social meanings of English. Sayer points out that students can act as investigators through conducting student-led projects exploring their local linguistic landscapes as such a practice helps students make "connections between the content of classroom lessons and the world beyond the classroom walls" (Sayer, 2010, p. 153) and think critically and creatively. It also helps them better understand their sociolinguistic environments, which leads to a better understanding of language awareness, use, and appropriateness. Likewise, Muth (2018) concludes that the use of LL contributes significantly to the development of literacy skills and pragmatic competence. Equally important, Muth (2018) argues that "research in linguistic landscaping opens up the potential to transform students into sociolinguists, critically reflecting on multilingual practices both in school and beyond.” (p. 213).

Rowland (2012) also examined the effectiveness of using the linguistic landscape as a pedagogical resource in EFL contexts. In his study, EFL students were required to take part in a project in which they collected and analyzed English texts displayed on public signs such as advertisements and road signs in Japan. The study concluded that the linguistic landscape can provide EFL students with pedagogical benefits such as the development of symbolic competence as well as literacy skills (Kramsch, 2009; Shohamy \& Waksman, 2009). In addition, Dumanig and David (2019) carried a study on the use of shop name signs for teaching purposes in Al Bruaimi region in Oman. The study was based on data obtained from students who were exposed to LL data (shop name signs) and asked to recall the English words and phrases they read and categorize them as function or content words. The study concluded that using LL data can help students develop their knowledge of vocabulary, spelling, and grammar. Finally, in their study of linguistic landscape in which three university students were required to do a LL project, Chestnut, Lee, and Schulte (2013) found out that such LL-based tasks contribute to the development of students' language abilities and intercultural communicative skills. 
For many years, the way language learning is understood was dominated by the view that "learning to read and write is seen as the point of education" (Barton, 1994, p. 176), and thus the skills acquired for school-approved textbooks are emphasized. This view has been challenged since the 1970s with recognition of the importance of language learning outside of school (Lankshear \& Knobel, 2011). Barton (1994) pointed out that, "everyday literacy gives a richer view of literacy which demands a new definition of literacy, a new way of thinking about what is involved in reading and writing" (p.5). In a study such as this that exploits linguistic landscape with a group of students, it is essential to take into consideration the students' awareness and perception of their linguistic landscape. The students' learning should not be limited to the materials based on their textbooks. Studies that explore the incongruities in the real-life use of English, such as the work of Dumanig and David (2019) are important as they suggest possible ways that the students' understanding of language and learning issues outside of school may be supported in the classroom.

Studies that investigate out-of-school language learning in the first language (L1) contexts are well documented in the field of literacy as social practice studies, for example, Heath (1981) and Street (1984). On the other hand, studies on out-of-school language learning in the second language (L2) contexts have been overlooked as the emphasis has been given to assist L2 students in their academic achievement relied heavily on the use of textbooks (Yi, 2005). Empirical investigations such as the studies carried out on a Cambodian immigrant (Skilton-Sylvester, 2002), a Chinese immigrant (Lam, 2000), and a group of Korean immigrants (Yi, 2005) found that the participants engaged with meaningful out-of-school language learning activities, echoing some results from L1 out-of-school language learning.

Rubinstein-Avila (2007) reported that her Latino immigrant students participate in L2 activities for three purposes. These were for entertainment, for seeking information, and for practicing English. The choice of language in their out-of-school language learning is crucial to our understanding of how students navigate their everyday literacy practices in bilingual and multilingual contexts. The argument made in this study is, for students to acquire English out-ofschool contexts, they need to be presented with the linguistic landscape that aids their learning of the target language and helps them develop translation skills.

Thus, based on the pedagogical benefits of LL for second and foreign language learning stated in the previous studies, the current study investigates the effectiveness of LL as a teaching and learning material for translation classroom to develop students' language and translation skills as well as critical literacy skills.

\section{Methodology \\ Context of the Study}

The site of the research is the city of Salalah. The site of the study is an integral part of the findings as it involved images of public signage and participants residing and studying in Salalah. The city of Salalah is the main city located in the governorate of Dhofar in the south of the Sultanate of Oman. Salalah is selected as the context for the study for the following two reasons. First, it is because the LL of this locale has not been studied from pedagogical perspectives. Second, Salalah comprises a large number of expatriate communities of diverse 
linguistic, cultural, and economic backgrounds, not to mention the status of the city as a tourist destination in the Gulf region.

With regards to the linguistic situation in this region, it is worthy to note that the indigenous population of Dhofar speaks local languages known as Jibbali and Mehri ${ }^{1}$ in addition to Arabic, which is the official language of the country. These local languages, as stated by Rubin (2014), do not have writing traditions, and as a result, they are not displayed in the linguistic landscape of the region.

Since the largest percentage of expatriate labor force such as those from Asian, western and African countries do not speak Arabic, the prevalence of English as a lingua franca and the role of English/Arabic/English translations in the city's linguistic landscape have been significantly increasing in order to maintain linguistic and cultural communication among foreign nationalities. Consequently, given such an ethnically and linguistically diverse population, the city has a huge number of bilingual public signs on which its linguistically diverse landscape is displayed.

\section{Participants}

The research samples consisted of 58 undergraduate students at Dhofar University, a higher learning institution in Oman. The type of sampling used in the study is a systematic sampling. The sampling criteria of the participants are: a) field of study, b) completion of at least two introductory translation courses and c) active enrolment in study programs. The participants are enrolled in two different programs of study, namely Bachelor in English Language and Bachelor in Translation Studies. All students who participated in the study have completed at least two introductory translation courses. By the completion of these courses, students are expected to be familiar with key concepts in translation theory, linguistic and extra-linguistic issues in translation and to have practiced translation from English into Arabic and vice versa.

\section{Data Collection Procedures}

The study aims to explore the pedagogical benefits of LL through the experiences of a group of students as part of the classroom teaching and learning. Paramount to achieving this aim is a research design that enables the students to engage with LL materials as part of the classroom discussion and to seek their perspectives on the use of LL through reflection activities. The reflection activities included focus group discussions and an online survey.

The course instructor presented the students with images of their LL and elicited information from the students through online classroom discussions. This involved four 50minute online sessions. All of the students enrolled in the particular translation courses engaged in the LL discussions because it is part of the students' course work. The students were invited to participate in an online focus group discussion after the lessons. An online survey comprised the Linkert scale, close-ended and open-ended questions were shared with the students. $80.2 \%$ of the overall students in the courses responded to the online survey.

The students' responses from the online survey were analyzed using IBM SPSS V26 software. The data gathered from the online survey generated information on their awareness of LL, perception on the use of LL in the classroom, and the students' perception of the errors in 
their LL. The survey included open-ended questions which sought an in-depth understanding of the participants' view of their LL. The students' open-ended responses were viewed closely for broad domains of analysis. A micro-level coding system was applied to tag units of data to organize and reorganize them to allow interpretation of the material.

\section{Findings}

\section{Finding one: Participants' awareness of their linguistic landscape}

The findings of the participants' awareness of their linguistic landscape were gathered from 58 participants $(n=58)$. Out of the 58 participants, $31 \%$ of the students responded that they were not aware of the errors in the translation of their linguistic landscape prior to the lesson. In a focus group discussion, the students revealed that they assumed the translation of their linguistic landscape was appropriate. The participants were tested to recall the errors of the images of the linguistic landscape that were discussed in the classroom. $82.7 \%$ of the respondents were able to recall and explain the translation errors. To test if there is an association between the students' reported awareness of their linguistic landscape and their perceived enjoyment of LL, T-test is applied.

Table 1. Summary of the participants' perceived enjoyment and increased awareness

\begin{tabular}{llr|r|r|r} 
& $\begin{array}{l}\text { Perceived enjoyment } \\
\text { of LL }\end{array}$ & $\mathrm{N}$ & Mean & $\begin{array}{c}\text { Std. } \\
\text { Deviation }\end{array}$ & \multicolumn{1}{c}{$\begin{array}{c}\text { Std. Error } \\
\text { Mean }\end{array}$} \\
\hline $\begin{array}{l}\text { Perceived increased } \\
\text { awareness }\end{array}$ & Yes & 52 & 4.46 & .699 & .097 \\
\cline { 2 - 7 } & No & 5 & 4.00 & .707 & .316 \\
\hline
\end{tabular}

Table 2. Independent samples T-test between the perceived enjoyment and increased awareness

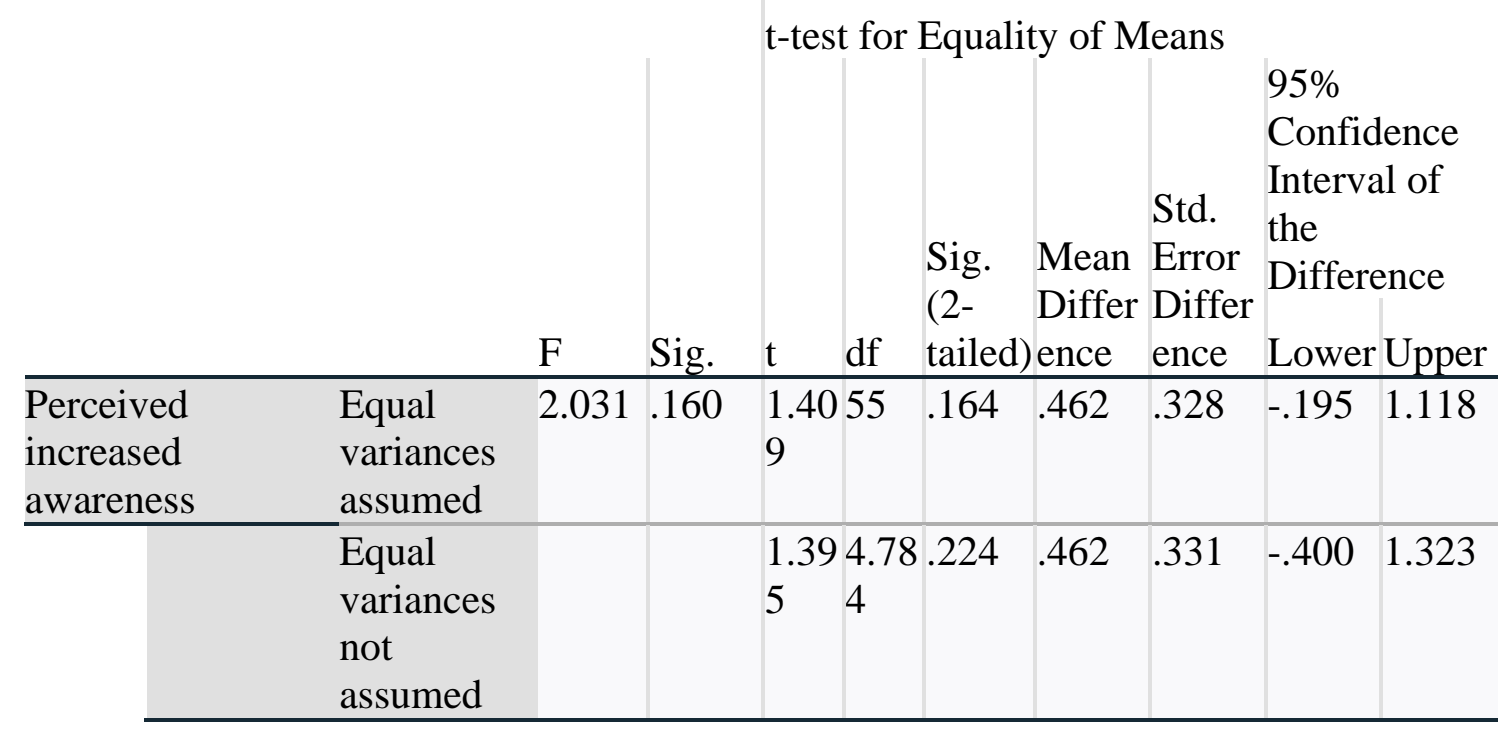


The p-value in Table two is $<0.5$ which indicates that there is a correlation between the students who enjoyed the lesson utilizing LL and their increased awareness of their LL.

The students' feedback from open-ended questions of the online survey revealed that their increased awareness of their linguistic landscape is one of the positive outcomes of the lesson. The following are excerpts taken from the feedback.

1. "I liked studying signs a lot, because I became more attentive to signs than before and increased my vocabulary, and it is fun to correct signs and correct mistakes as an educational game" (S2)

2. "The most thing I like it is I know now what is wrong translation of public signage so I can now distinguish the wrong and the right translation" (S51).

3. "It was so helpful and the same time funny to see the mistakes in translation because I did not pay attention to such things before. After this session, I am sure that I will assess the signs more and I will see which type of translation is used" (S9).

In addition to the findings above, $91 \%$ of the respondents of the study reported that they would actively look around their LL for errors after the particular lessons.

Finding two: The perspectives of the participants on the use of linguistic landscape as part of the classroom instruction

The students' perspectives of the use of LL as part of the classroom instruction were gathered from 58 respondents. The students' feedback was gathered from open-ended questions of the online survey. The responses were viewed closely to identify a suitable frame for analysis. The broad domains that were derived from the questions were coded as follows: bridging theory and practice, improved language learning skills, and participation in the community. Each of these is described in turns.

\section{Bridging Theory and Practice}

All of the participants enjoyed the lessons utilizing LL as part of the classroom instruction, of which $98.2 \%$ reported that the use of LL as part of the classroom instruction aided their understanding of the translation theories. The following are excerpts from the feedback the students wrote.

1. "I believe that this lesson is one of the most beautiful and useful lessons that we have gone through, because it allowed us to apply what we have learned and to relate translation theories to the environment around us" (S23).

2. "We get to see examples from real life of what we learned theoretically, so it made it obvious and easy for us to grasp the concepts" (S11).

3. "I have learned to apply what I have studied in theoretical lessons in the real life" (S17).

\section{Improved Language Learning Skills}

The ability to identify the translation errors in the linguistic landscape requires the understanding of the source text and the formulating of the target text. It also requires proficiency in understanding the language aspects of both languages. In the context of this study, the languages involved are Arabic and English. The cultural nuances of the two languages are influenced by other languages as described in the Methodology section. The participants of the study attributed improved English language skills and the ability to apply translation theories into real-life language use. To test if there is an association between the students' application of 
theories and their perception of their improved language learning skills, the Pearson Correlation test is applied.

Table 3. Correlation between students' ability to apply translation theories and improved language skills

\begin{tabular}{llr|r} 
& & $\begin{array}{c}\text { Application of } \\
\text { theories }\end{array}$ & $\begin{array}{c}\text { Perceived } \\
\text { improved } \\
\text { language skills }\end{array}$ \\
\hline Application of theories & Pearson Correlation & 1 & $.308^{*}$ \\
\cline { 2 - 4 } & Sig. (2-tailed) & 57 & .020 \\
\hline Perceived improved & $\mathrm{N}$ & $.308^{*}$ & 57 \\
language skills & Pearson Correlation & .020 & 1 \\
\hline & Sig. (2-tailed) & 57 & 57 \\
\hline
\end{tabular}

The p-value is $<0.5$ which indicates that there is a correlation between the students' perceived ability to apply theories of translation and their perceived improved language skills.

The responses to the open-ended questions of the survey revealed similar findings. The following are the excerpts of the responses.

1. "I like that I learn grammar and vocabulary also we can assist translation .and I like that know I can correct the translation" (S3)

2. "I learned more words" (S49)

3. "I learned the appropriate use of the language and how to avoid the linguistic mistakes" (S30).

In addition to the above, 55 respondents preferred learning English through real-life language use, such as LL as part of classroom instruction. $96.5 \%$ of the respondents found the lesson engaging as it motivated them to participate in the classroom discussions.

\section{Participation in the Community}

The domain of Participation in the Community is derived from Oman National Education Strategy for 2040. The students' responses for this domain are divided into the following subcategories: being critical of their own community and empowering students as agents of change.

\section{Being Critical of their Community}

$87.9 \%$ of the students find that inaccurate translation of LL gives a negative image of Salalah to people visiting the city. The students responded in the open-ended question as follows:

1. "In my view, it is important because it will reflect the extent of the development of the city and the learning of its inhabitants" (S9)

2. "It reflects the image of local people, so foreigners might think that local people are not educated enough" (S7). 


\section{Empowering Students as Agents of Change}

$84.4 \%$ of the respondents reported that the awareness of LL made through the lessons motivated them to be the agents of change. In a focus-group discussion, the students commented that they are motivated to engage with the Dhofar Municipal Council and business Registration Office in the future to ensure that their LL is represented accurately.

\section{Finding three: The course instructor's reflection on the lesson delivery utilizing LL as a teaching and learning resource}

As an instructor of translation courses, the researcher often uses a variety of teaching materials such as newspaper articles, short stories, business, legal and technical texts to allow students to practice translation and develop their language and translation skills. However, having noticed that translation students' exposure and practice outside classrooms are limited as the resources and materials available for them are often textbook-based, and thus can be not very related to learners' environment, culture, and experience, the researcher explored the potential of utilizing language texts publically displayed in the students' community as a teaching and learning resource to enhance students' literacy development as well as their language and translation skills.

Bearing in mind that learning can take place outside classroom settings (Sayer, 2010) and that such a learning environment can contribute to the development of learners' language awareness, critical thinking, pragmatic and symbolic competence, etc (Wiśniewska, 2020; Gorter \& Cenoz 2015; Rowland 2012; Sayer 2010), the researcher conducted four 50-minute sessions online using monolingual and bilingual (translated) public signs as a pedagogical tool to enhance learners' language awareness and help them apply the translation theories they studied to translations of public signs in their local communities. The sessions aimed to connect students to the linguistic realities and translation practices they encounter outside the classroom and determine to what extent such a practice can be pedagogically beneficial. It is worth noting that the use of public signage translations as a resource in language and translation classrooms is underutilized; based on my observation as well as students' responses to the questionnaire, teachers seem not to make use of such a resource to promote students' language, translation and literacy skills.

The classroom discussions are framed with the following "grand-tour" (Spradley, 1979, p. 79) questions: what languages are used in your community? Why is English used on public signs? Why are most of the public signs translated into English? Are the translations of public signage appropriate, informative and communicative? Such questions aimed to creatively and critically engage students with the texts on the signs by presenting and defending their interpretations of the texts on the signs. Based on the discussion and analysis of scripts on monolingual and bilingual pubic signs, some findings have been reached. The findings are presented below as themes derived from the instructor's observations made during the classroom discussions.

\section{Awareness of Language Use and Function}

Through the discussion and analysis of LL texts in class with respect to language function and use in the locale understudy, students learned more about the languages that are relevant and used in their social context, taking into account the fact that there exist several languages spoken 
in the Dhofar region. Students learnt about the social functions of language; for instance, they stated that some public signs are mainly used to convey information to non-Arabic speakers such as tourists, visitors, or expatriate audience, showing the use of English as a lingua franca; others, such as advertisements, are used to attract people to services and products.

\section{Enhancement of Translation, Critical Thinking \& Creativity Skills}

The use of bilingual public signs (signs with translational content) provides students with an opportunity to put into practice the translation theories they studied in class through discussing, assessing, and commenting on existing public signage translations. Furthermore, the use of LL material for teaching and learning purposes renders the learning process more exciting and motivating, which encourages learners to engage more actively and creatively with language texts. Most students were engaged in discussions on public signs by presenting and defending their ideas regarding issues such as their assessment of public signage translations and how to improve the quality of existing translations, which eventually helps in the development of students' critical and analytical skills.

\section{Enhancement of Foreign Language Proficiency}

The use of LL gave learners the opportunity to identify language inaccuracies, which contributes to the enhancement of their foreign language proficiency. It also makes them aware of the linguistic features of their local linguistic landscape. During the sessions, students, for instance, noticed and identified a number of grammatical and lexical inaccuracies while analyzing LL texts in class, and they commented on how such inaccuracies affect the meaning and perception of the text by the target audience.

\section{Empowerment of Students' Role in the Community}

During the lessons, the students developed an awareness of both the importance of the linguistic landscape and the quality of their community linguistic landscape. Having been aware now that the linguistic landscape of a locale can give a positive or negative view, students expressed their willingness to actively take part in any attempt aiming to improve the quality of the linguistic landscape in their local communities. Given that the participants are expected to work as teachers, translators, and/or language editors or proof-readers, they are aware now of the current situation of their community LL and what should be done to improve its quality and present it more appropriately. In this respect, most students expressed an interest in raising awareness among their fellow students, family members, relatives, and friends about the importance of linguistic landscape not only as a medium of communication but also as a learning space and a space of linguistic diversity that can reflect an image on the community.

\section{Discussion of the Findings}

The study focused relatively on a small sample of undergraduate students at Dhofar University in Oman $(n=58)$. All of the participants are able to effectively communicate in Arabic and English. A large percentage of the participants are also able to communicate in the local languages spoken in the Dhofar region, i.e. Jibbali and Mehri.

The LL data used as a teaching and learning resource for the study consisted of a corpus of 20 digital photos of public signs. Methodologically, as pointed out by Hult (2009), linguistic landscape data analysis relies mainly upon photography and visual analysis. Thus, in line with 
previous LL studies, e.g. Sayer (2010), Cenoz and Gorter (2008), Backhaus (2007), and BenRafael et al., (2006), digital photography was used as a data collection method to compile a corpus of 20 digital photos of non-official public signs of commercial nature, including signs on shops, cafes, restaurants, and other commercial places. The photos of public signs were taken and documented in fieldwork visits to different parts of Salalah city in June and July of 2020.

The majority of the respondents reported increased awareness of their LL through classroom discussions. A small percentage of the students (31\%) were not aware of the translation errors in their LL before the lesson and accepted the translation as accurate. The false impression of the language in their LL may negatively impact the students' understanding of the target language use, in the case of this study, English. The students' increased awareness of their LL echoes the findings of Cenoz' and Gorter's study (2008) and that of Gorter (2017) that uncovered the relationship between the learners' exposure to the language scripts of public signage and their language awareness. The data of the students' enjoyment of the lesson, preferred authentic real-life language use and their ability to recall translation errors as reported in this study serves for the consideration of language and translation teachers to utilize LL as part of their classroom instruction. These findings were also reflected in the previous research such as the works of Sayer (2010) and Hewitt-Bradshaw (2014).

The findings of the study also revealed that the students perceived the use of LL as part of the classroom discussion positively. The responses from the students and the reflection of the course instructor revealed that by utilizing LL in the classroom, the students were encouraged to actively participate in the classroom discussions. The majority of the participants (98.2\%) reported that the use of LL as part of the classroom discussion aided their understanding of translation theories. The study also showed high enjoyment of the lessons and a positive correlation ( $\mathrm{p} .<0.5)$ between the students' perceived ability to understand the translation theories and improved language skills. These two skills are crucial for the students' careers as translators and language instructors. Hewitt-Bradshaw's (2014) study on LL observed similar results. The study concluded that the use of public texts in the classroom offered strengths in three areas, namely: language awareness, communicative competence, and process of language learning more interesting and appealing. One of the crucial findings of the study is the motivation of the students to engage with their local community in the future. The awareness of their LL, and the discussion they had with their course instructor and peers motivated the students to actively look around for LL errors, engage with the Municipal Council and business registration offices in the future to ensure their LL is accurate and well-represented. The students' motivation to be critical and to actively participate in the development of the Sultanate is an important aspect outlined in Oman National Education Strategy 2040.

In addition, the study showed that students developed an awareness of language use and function in society (Gorter, 2017). They, for instance, recognized that in their community English is used as a lingua franca to serve as a means of intercultural communication among expatriate communities. The students also noticed that some signs, especially those displaying national flags and universal landmarks considered as cultural icons, as shown in Figure one, are used to express social meanings (Sayer, 2010), such as prestige, modernity, and associations with foreign cultures as English, French and Italian, etc (Blommaert, 1996; Backhaus 2007, Torkington, 2009). 


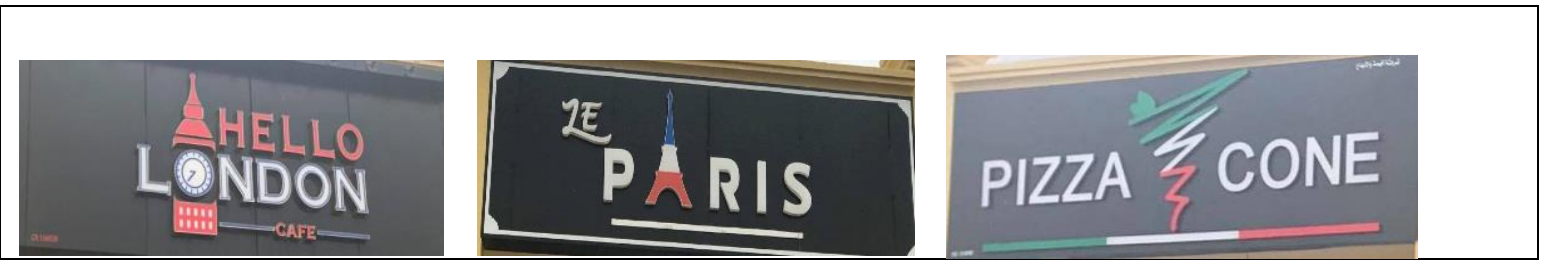

Figure 1. Signs expressing different social meanings

Thus, it can be concluded that the use of LL materials can encourage students to look critically at the scripts displayed in their LL communities questioning how and why individuals use language differently in accordance with different social contexts and purposes (Shohamy \& Waksman 2009; Sayer, 2010; Muth, 2018). Furthermore, the use of LL as a learning resource showed that it contributes to the development of learners' foreign language knowledge and awareness as this helps learners gain a better understanding of the social, cultural, and economic values associated with the use of English, for instance, as a global language in their local community (Sayer, 2010; Rowland, 2012; Gorter, 2017; Wiśniewska, 2020).

The study showed that the discussion of public signage translations encouraged the students to engage more critically and creatively with the existing translations of their LL and gave them the opportunity to assess their quality and propose more adequate translations. The students, for instance, considered the translations in Figure two inaccurate due to the improper use of omission as a translation strategy. They noticed that the non-translation of the lexical items 'تأجير' and 'الإنجليزية' in Signs one and two respectively distorted the source text meaning and gave rise to meanings different from those intended in the source texts. The students stated that it is not clear from the English translation in Sign one whether the store provides sale, rental, or fixing services to customers. Likewise, the omission (non-translation) of the word 'الإنجليزية in Sign 2 creates ambiguity because, as the students reported, it is not clear for non-Arabic speakers what languages are taught at the institute.

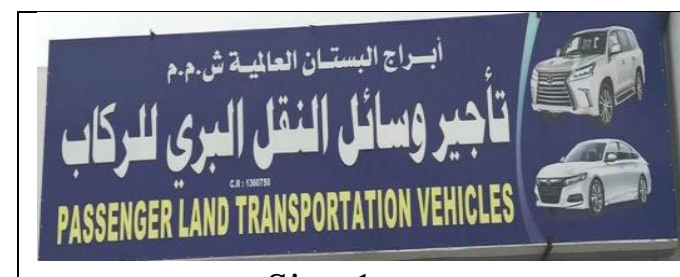

Sign 1

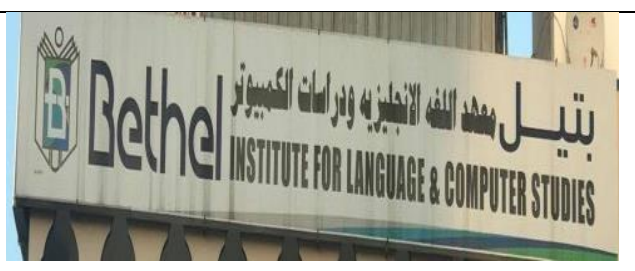

Sign 2

Figure 2. Signs showing translation errors

More importantly, as a pedagogical benefit of discussing public signage translations, creativity was attested as students proposed translations they considered more appropriate, informative, and communicative based on their diagnosis of the context and the background of the target text audience. For instance, they proposed 'Rental of Land Transportation Vehicles' and 'Car Rentals' as translations for the text in Sign one, and 'Bethel Institute for English Language and Computer Studies' as an appropriate rendering for the text in Sign two. Thus, it is concluded that such a LL discussion activity promotes the development of translation knowledge and skills as it provides learners with the opportunity of connecting what they learn in class to language texts 
displayed in their community. Equally important, it encourages them to be critical in the sense that they question translated texts on public signs they encounter outside the classroom, contributing to the enhancement of their incidental learning, i.e. "learning without the intent to do so" (Cenoz \& Gorter, 2008, p. 272).

\section{Conclusion}

The research has examined the utilization of students' linguistic landscape for the enhancement of learners' language awareness, translation, and literacy skills. The study revealed three major findings. First, through the use of LL as a pedagogical resource in the classroom, the students have become more aware of their own linguistic landscape. Second, the students perceived the use of LL in the classroom positively and attributed it to their improved language skills and ability to draw links between translation theories and practice. The students also reported that the use of LL as part of the classroom learning enabled them to participate in their own communities by being critical of the public signage in their environments, empowering them to be the agents of change in the future. Lastly, the course instructor's reflection showed that the use of LL provided the students with the opportunity to develop their creativity, critical thinking, and literacy skills.

Although the study focused on a small sample of students, it has important pedagogical implications. The technique of utilizing LL scripts that the participants are familiar with motivated them to actively and creatively engage in classroom discussions. The statistical findings and feedback received from the participants on the use of LL as a teaching and learning resource showed positive outcomes such as enhancement of language and literacy skills. Furthermore, the course instructor uncovered the effectiveness of LL for the development of students' creativity and critical thinking skills, which are crucial skills in the $21^{\text {st }}$ century. The implication of the study is not only to draw attention to the usefulness of LL as a learning space and the quality of the participants' local LL, but also to invite learners to actively take part in improving the quality of their communities' linguistic landscapes, given that they are the prospective language specialists and translators who are expected to provide language and translation services for private and government sectors.

\section{Endnotes}

${ }^{1}$ Jibbali and Mehri are Semitic Modern South Arabian languages. See Rubin (2014) for further information on Modern South Arabian languages.

\section{About the authors}

Ali Algryani is an assistant professor of Linguistics and Translation Studies at Dhofar University, Oman, and The Libyan Academy, Tripoli, Libya. He received his $\mathrm{PhD}$ from Newcastle University School of English Literature, Language \& Linguistics. His research interests are comparative syntax, translation studies, sociolinguistics and second and foreign language pedagogy. ORCid ID: https://orcid.org/0000-0002-2806-6680

Syerina Syahrin is a faculty member of Dhofar University. She was the recipient of Victoria Award of Excellence, New Zealand, Erasmus+ Mobility, and was a visiting academician in Thailand. Syerina's research interests include teaching linguistically diverse students, inclusive 
Arab World English Journal (AWEJ) Volume 12. Number 1. March 2021

Utilizing Learners' Linguistic Landscape as a Pedagogical Resource

Algryani \& Syahrin

pedagogy, and internationalization of education. ORCid ID: https://orcid.org/0000-0002-9214$759 \mathrm{X}$

\section{References}

Backhaus, P. (2007). Linguistic landscapes: A comparative study of urban multilingualism in Tokyo. Clevedon-Buffalo-Toronto: Multilingual Matters Ltd.

Barton, D. (1994). Literacy: An introduction to the ecology of written language. Oxford: Blackwell.

Ben-Rafael, E., Shohamy, E., Amara, M., \& Trumper-Hecht, N. (2006). Linguistic Landscape as Symbolic Construction of the Public Space: The Case of Israel. International Journal of Multilingualism, 3(1), 7 - 30. DOI: 10.1080/14790710608668383

Blommaert, J. (1996). Language planning as a discourse on language and society: the linguistic ideology of a scholarly tradition. Language Problems and Language Planning, 20(3), 199-222. DOI: https://doi.org/10.1075/lplp.20.3.01blo

Cenoz, J., \& Gorter, D. (2008). The linguistic landscape as an additional source of input in second language acquisition. International Review of Applied Linguistics in Language Teaching, 46(3), 267-287. DOI:10.1515/IRAL.2008. 012

Chesnut, M., Lee, V., \& Schulte, J. (2013). The language lessons around us: undergraduate English pedagogy and linguistic landscape research. English Teaching: Practice and Critique. 12 (2), 102-120.

Dagenais, D., Moore, D., Sabatier, C., Lamarre, P., \& Armand, F. (2009). Linguistic landscape and language awareness. In E. Shohamy, \& D. Gorter (Eds.), Linguistic landscape: Expanding the scenery (pp. 253-269). London, UK: Routledge.

Dumanig, F. P., \& David, M. K. (2019) Linguistic Landscape as a Pedagogical Tool in Teaching and Learning English in Oman. Modern Journal of Studies in English Language Teaching and Literature, 1, 1-13.

Floralde, R., \& Valdez, P. N. (2017). Linguistic landscapes as resources in ELT: The case of a rural community in the Philippines. Journal of Asia TEFL, 14(4), 793.

Gorter, D. (2006). Further Possibilities for Linguistic Landscape Research. In D. Gorter, (Ed.). Linguistic Landscape: A New Approach to Multilingualism, (pp. 81- 89). Clevedon: Multilingual Matters.

Gorter, D. (2017). Linguistic landscapes and trends in the study of schoolscapes. Linguistics and Education, 44, 80-85. DOI: https://doi.org/10.1016/j.linged.2017.10.001

Gorter, D., \& Cenoz, J. (2015). The linguistic landscapes inside multilingual schools. In Groter, D. (eds.) Linguistic Landscape: Expanding the Scenery. (pp. 88-104). London, UK: Routledge.

Heath, S. B. (1981). Toward an ethnohistory of writing in American education. In M.F. Whiteman (Ed.), Writing: The nature, development, and teaching of written communication, 1, Variation in writing: Functional and linguistic-cultural differences (pp. 25-45). Hillsdale, NJ: Erlbaum.

Hewitt-Bradshaw, I. (2014) Linguistic Landscape as a Language Learning and Literacy Resource in Caribbean Creole Contexts. Caribbean Curriculum, 22, 157-173.

Hult, F. M (2009) Language Ecology and Linguistic Landscape Analysis. In Shohamy, E. \& Groter, D. (eds.) Linguistic Landscape: Expanding the Scenery. (pp. 88-104). London, UK: Routledge. 
Arab World English Journal (AWEJ) Volume 12. Number 1. March 2021

Utilizing Learners' Linguistic Landscape as a Pedagogical Resource

Algryani \& Syahrin

Kasanga, L. A. (2012). Mapping the linguistic landscape of a commercial neighbourhood in Central Phnom Penh. Journal of Multilingual and Multicultural Development, 33(6), 553 - 567. https://doi.org/10.1080/01434632.2012.683529

Kramsch, C. (2009). The multilingual subject. Oxford: Oxford University Press.

Lam, W. S. E. (2000). L2 literacy and the design of the self: A case study of a teenager writing on the Internet. TESOL Quarterly, 34(3), 457-482. https://doi.org/10.2307/3587739

Landry, R., \& Bourhis, R. (1997) Linguistic landscape and ethnolinguistic vitality: An empirical study. Journal of Language and Social Psychology, 16(1), 23-49. doi:10.1177/0261927X970161002

Lankshear, C., \& Knobel, M. (2011). New literacies. UK: McGraw-Hill Education.

Malinowski, D. (2015) Opening spaces of learning in the linguistic landscape. Linguistic landscape, 1(1-2), pp.95 - 113. DOI: https://doi.org/10.1075/11.1.1-2.06mal

Martin-Jones, M., \& Bhatt, A. (1998). Literacies in the lives of young Gujarati speakers in Leicester. In A.Y. Durgunoglu, \& L. Verhoeven, (Eds.), Literacy development in a multilingual context: Cross-cultural Perspectives (pp. 37-50). Mahwah, New Jersey: Lawrence Erlbaum.

Muth, S. (2018) Linguistic Landscaping. In A. Bonnet \& P. Siemund, (Eds.) Foreign Language Education in Multilingual Classrooms (pp.213-235) Hamburg Studies on Linguistic Diversity. John Benjamins Publishing Company.

Roos, J., \& Nicholas, H. (2019) Using young learners' language environments for EFL learning: ways of working with linguistic landscapes. AILA Review, 32, (1), 91 -111.

DOI: https://doi.org/10.1075/aila.00022.roo

Rowland, L. (2012). The pedagogical benefits of a linguistic landscape project in Japan. International Journal of Bilingual Education and Bilingualism, 16 (4)1-12. doi: 10.1080/13670050.2012.708319

Rubin, A. D. (2014). The Jibbali (Shahri) language of Oman: grammar and texts. Brill.

Rubinstein-Avila, E. (2007). Reductive literacies: Ethnographic vignettes of content area classes for middle school Latino/a students. In EMIGRA working papers, 96, 1-16. Retrieved from https://ddd.uab.cat/pub/emigrawp/emigrawp_a2007n96/emigrawp_a2007n96p1.pdf

Sayer, P. (2010) Using the linguistic landscape as a pedagogical resource. English Language Teaching Journal, 64(2), 143-154. DOI:10.1093/elt/ccp051

Shohamy, E., \& Gorter, D. (Eds.). (2009). Linguistic landscape: Expanding the scenery. London, UK: Routledge.

Shohamy. E., \& Waksman, S. (2009). Linguistic landscape as an ecological arena:Modalities, meanings, negotiations, education. In E. Shohamy, \& D. Gorter, (Eds.), Linguistic landscape: Expanding the scenery (pp. 313-331). London, UK: Routledge

Skilton-Sylvester, E. (2002). Literate at home but not at school: A Cambodian girl's journey from playwright to struggle writer. In G. Hull, \& K. Schultz, (Eds.), School's out!: Bridging out-of-school literacies with classroom practice (pp. 61-90). New York: Teachers College Press.

Spolsky, B. (2009) Prolegomena to A Sociolinguistic Theory of Public Signage. In E. Shohamy, \& D. Gorter, (Eds.), Linguistic landscape: Expanding the scenery (pp. 25-39). London, UK: Routledge

Spradley, J.P. (1979). The Ethnographic Interview. CA: Wadsworth

Street, B. (1984). Literacy in theory and practice. Cambridge: Cambridge University Press.

Torkington, K. (2009). Exploring the Linguistic Landscape: the case of the 'Golden 
Triangle' in the Algarve, Portugal. In S. Disney, B. Forchtner, W. Ibrahim, \& N. Miller, (Eds.), Papers from the Lancaster University Postgraduate Conference in Linguistics \& Language Teaching, (Vol. 3, pp 122-145).

Wiśniewska, D. (2020) Linguistic landscape, murals and language learning. In S. AdamczakKrysztofowicz, A. Szczepaniak-Kozak \& P. Rybszleger (Eds.) Applied Linguistics: New challenges and concepts. (pp. 429-446). Göttingen: Vandenhoeck \& Ruprecht Publishers

Yi, Y. (2005). Immigrant Students' Out-of-School Literacy Practices: A qualitative study of Korean Students' Experiences, (Unpublished Doctoral dissertation). The Ohio State University, USA . Retrieved from

https://etd.ohiolink.edu/!etd.send_file?accession=osu1118856037\&disposition=inline 